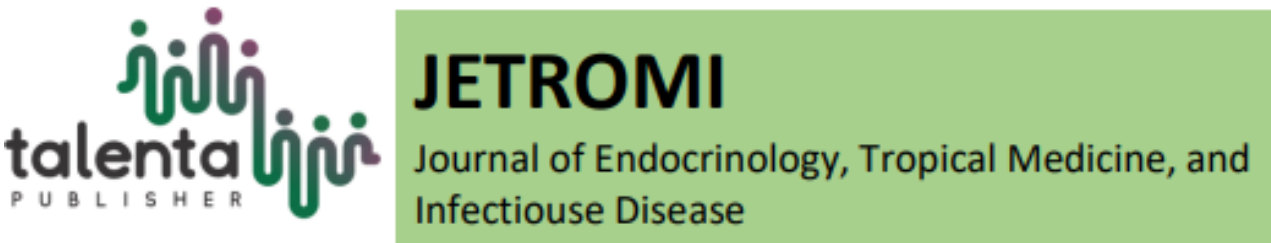

\title{
Correlation Between Duration of Protease Inhibitor Therapy With Insulin Resistance in HIV Patients
}

\author{
M. Arif Habibi Nasution", Melati Silvanni Nasution², Dian Anindita Lubis ${ }^{2}$ \\ ${ }^{1}$ Department of Internal Medicine, Faculty of Medicine, Universitas Sumatera Utara \\ ${ }^{2}$ Division of Endocrinology Metabolic and Diabetes, Department of Internal Medicine, Faculty of \\ Medicine, Universitas Sumatera Utara
}

\begin{abstract}
A large number of literature and study that are published discuss about the correlation between the use of antiretroviral (ARV) with insulin resistance, especially protease inhibitors. This study's objective is to assess the correlation between duration of administration of protease inhibitors and insulin resistance in HIV-patients. An observational research was conducted in Polyclinic of Special Service Center (Posyansus) for HIV patients at H. Adam Malik General Hospital from August - December 2019, and the data was analysed using Chi-Square test. The subjects were $34 \mathrm{HIV}$-patients treated with protease inhibitor. The average age of the subjects range from 34 - 49 years $(54.3 \%)$, men $(71.4 \%)$ and women $(28.6 \%)$. Most of the subjects use ARV drugs from 6-12 months (60\%). In which 13 people $(37.1 \%)$ has insulin resistance. The average HOMA-IR value was 2 (0.8-16.5), fasting blood sugar levels were $86(70-283) \mathrm{mg} / \mathrm{dl}$, fasting insulin levels were 9.1 (4.1-79.4) $(\mu \mathrm{U} / \mathrm{ml})$., urea levels of $20.88 \pm 9.7 \mathrm{mg} / \mathrm{dl}$ and creatinine levels of $0.81 \pm 0.15 \mathrm{mg} / \mathrm{dl}$. There was a significant correlation between the duration of ARV treatment with insulin resistance. The prolonged use of Protease Inhibitors will further increase insulin resistance.
\end{abstract}

Keywords: HIV, Protease Inhibitors, Insulin Resistance

\begin{abstract}
Abstrak. Banyak literatur dan penelitian yang membahas mengenai hubungan penggunaan ARV dengan resistensi insulin, khususnya protease inhibitor. Penelitian ini bertujuan untuk mengetahui hubungan lama pemberian protease inhibitor dengan resistensi insulin pada pasien dengan HIV. Penelitian observasional dengan desain studi cross sectional, dengan analisis statistic menggunakan uji chi-square. Penelitian dilakukan di Poliklinik Pusat Pelayanan Khusus (Pusyansus) RSUP H. Adam Malik bulan Agustus - Desember 2019. Sampel penelitian berasal dari pasien HIV yang mendapat terapi ARV jenis protease inhibitor sebanyak 34 orang. Karakteristik subjek penelitian memiliki rentang usia terbanyak pada usia 34 - 49 tahun yaitu sebanyak 19 orang (54,3\%), laki-laki sebanyak 25 orang $(71,4 \%)$ dan perempuan sebanyak 10 orang (28,6\%). Lama pemakaian obat ARV paling banyak pada kelompok 6-12 bulan yaitu sebanyak 22 orang (60\%). Resistensi insulin pada penelitian ini sebanyak 13 orang $(37,1 \%)$. Nilai median HOMA-IR subjek penelitian sebesar 2 (0,8-16,5), gula darah puasa (GDP): 86(70-283) $\mathrm{mg} / \mathrm{dl}$, kadar insulin puasa: 9,1 (4,1-79,4) ( $\mu \mathrm{U} / \mathrm{ml})$, kadar ureum: 20,88 $\pm 9,7 \mathrm{mg} / \mathrm{dl}$ dan kadar kreatinin 0,81 $\pm 0,15 \mathrm{mg} / \mathrm{dl}$. Terdapat hubungan yang signifikan antara lama pengobatan ARV dengan resistensi insulin.. Semakin lama penggunaan Protease Inhibitor akan semakin meningkatkan resistensi insulin.
\end{abstract}

Kata Kunci: HIV, Protease inhibitor, Resistensi Insulin

\footnotetext{
*Corresponding author at: arifnst91@ gmail.com, Department of Internal Medicine, Faculty of Medicine, Universitas Sumatera Utara, Indonesia

E-mail address: arifnst91@gmail.com
} 


\section{Introduction}

Human Immunodeficiency Virus (HIV) is one of the diseases that has continued to grow from year to year. World Health Organization (WHO) and UNAIDS reported there was 39.5 million people has been diagnosed with HIV across the world and about 2 million people in Latin America [1]-[2].

A large numbers of literature and study that are published discuss about the correlation between using antiretroviral (ARV) with insulin resistance, however only a few that discuss about the correlation in HIV patient, regarding the activity of ARV in process of insulin resistance. In vitro study show the use of Protease Inhibitor (PI), include ritonavir, may acutely cause the inhibition activity of glucose transporter-4 (GLUT-4) that can cause insulin resistance in normal patient and HIV-positive patients that have lipodystrophy [3]-[4].

Insulin resistance found in $21 \%$ HIV patients who in on going ARV treatment. In vitro study and single drug research on healthy patient dan infected with HIV has proven that IR may induced by ARV [5].

Few studies report that the cause of insulin resistance in number HIV patients is PI (protease inhibitor). This can be explained by three assumption: in the plasma membrane the activity of GLUT-1 and GLUT-4 were restricted, inhibition from differentiation of pre adipocyte/adipocyte, and induced apoptosis in adipose tissue. Research by Murata and Hruz et al in [6], suggest that the inhibition of GLUT-4 was the primary mechanism accountable in an induced insulin resistance.

Few studies analyzed correlation between insulin resistance with use of ARV, especially PI-type in HIV-positive patients. Koster et al in [7] found that PI in therapeutic dose was enough to induced insulin resistance and beta pancreas cell damage in mice. This study used indinavir as ARV and the method to look insulin resistance that used is hyperglycaemic clamps. Gullein et al in [2], stated there was a correlation between use of ARV and insulin resistance. In that study, insulin resistance prevalence is $34 \%$, two times higher than patient without HIV. The research of metabolic evaluation in treatment-naives assesing the impact of two boosted PI on lipids and other markers, a randomized study using 4 phase that was conducted by Overton et al in [8], compared the metabolic adverse effect of darunavir/ritonavir with atazanavir/ritonavir using hyperinsulinemic euglycemic clamp methods. That research concluded that after 48 weeks of consuming the combination of darunavir/ritonavir with atazanavir/ritonavir, the drugs has no significant effect to insulin resistance. [8]-[9]

Research about the duration of ARV treatment especially relate to monitoring the occurrence of side effects of insulin resistance has a different duration. Noor et al in [10] report that administration of LPV/r (lopinavir/ritonavir) for 5 days can induced insulin resistance, however in this study the effect of LPV/r were not analysed in longer duration. According to Permenkes in [11] reported on the use of ARV has a different variation of time to the showing 
signs of toxicity. Abnormalities that appear related to metabolic such as insulin resistance are begin to occur on ARV use for 6-18 months.

The difference on few result researches regarding the effects of PI in insulin resistance in HIV patients attract the attention of researchers to re-examine the correlation between the administration of PI to insulin resistance in HIV patients. Compared to some previous research, this is the first research that focuses to investigate the correlation between the duration of ARV with the incidence of insulin resistance in HIV patients, particularly in Medan.

\section{Methods}

This research is an observational research using a cross sectional design and is analysed using Chi-Square test. The study was conducted in a special service center for HIV patients in H. Adam Malik General Hospital from August to December 2019. Every patient that came to the clinic who had been diagnosed with HIV and receiving therapy using ARV that contain PI was given a questionnaire. This study had several inclusion criterias that consist of : HIV patients who had received therapy using PI, patients that have been treated for longer than 6 months, and patient who were 18 above in age. All of the patients was tested for fasting blood glucose, and using fasting insulin levels to establish signs of insulin resistance. Blood glucose levels were examined using the glucose oxidase method, hyperglycemia was considered if fasting blood glucose level $\geq 100 \mathrm{mg} / \mathrm{dL}$. Insulin testing was carried out using chemiluminescent (sandwich) immunoassay with substance such as serum/ plasma Li-heparin / plasma K3-EDTA / plasma sodium citrate. The presence of insulin resistance was determined using mathematical model of Homeostasis Model Assessment-Insulin Resistance (HOMA-IR) with the formula [Fasting insulin levels $[\mu \mathrm{U} / \mathrm{ml} \times$ fasting blood glucose $(\mathrm{mmol} / \mathrm{L}) / 22,5)]$. The author defined insulin resistance as HOMA-IR level is $\geq 2.6$ [12]. Period of treatment using PI was the independent variable of this research, while the dependent variable is insulin resistance.

\section{Result dan Analysis}

\subsection{Subjects Characteristic}

This research involves 35 research subject which have fulfilled the inclusion criteria. From the total of 35 subject. there were 10 females $(28,6 \%)$, and 25 males $(71.4 \%)$. With the median age of 38,85 years. the average age of the subject range from 34-49 years is 19 subjects $(54,3 \%)$. The same results were found in research that was conducted by Mulyati et al in [14] who reported that more males (67\%) have HIV instead of females (33\%) with an overall age average of $3.71 \pm 10.7$ years. Araujo et al in [13], also reported the same results in which $75 \%$ of men that have HIV were in the age range of 39-49 years old. A research shows that infection of HIV occurred more frequent in younger age range from 12-35 years, this result is probable 
due to the fact that a lot of younger people do not use protection while engaging in sexual intercourse. Protection in this context is using a condom, frequent changes in partners and drugs abuse or consumed alcohol [15].

The mean Body Mass Index (BMI) of subject is $24.35 \pm 3.99 \mathrm{~kg} / \mathrm{m}^{2}$, and as much as 13 $(37,1 \%)$ were categorized as normoweight. The mean systolic pressure is $110(100-130) \mathrm{mm} \mathrm{Hg}$ and the diastolic pressure is $70(60-90) \mathrm{mm} \mathrm{Hg}$. From these results it can be concluded that the average BMI is overweight but the highest percentage is normoweight while for the blood pressure is still within normal limits. This result concedes by the study that was conducted by Araujo et al in [13] who reported that the mean BMI of HIV patients receiving ARV was $23.9 \mathrm{~kg} / \mathrm{m}^{2}$

The mean results HOMA-IR value of the research subject was $2(0.8-16.5)$. The subjects who experienced insulin resistance in this study were 13 people $(37.1 \%)$. The prevalence of this results is slightly higher than previous studies conducted by Gullein et al in [2] who reported the prevalence of insulin resistance of $34 \%$, twice as high as in a population of patients without HIV with a HOMA-IR value of $\geq 2.1$. In line with this, Salazar et al in [16] reported HOMA-IR values $>2$ related to insulin resistance.

The subject that use of PI-type of ARV drugs in this study mostly ranged between 6-12 months, as many as 22 people $(60 \%)$. Research on the use of antiretroviral drugs, especially related to monitoring the occurrence of side effects of insulin resistance has a different duration. Noor et al in [10] reported that the administration of LPV / r (lopinavir / ritonavir) for 5 days could induce insulin resistance, but in this study the effect of LPV / $\mathrm{r}$ were not assessed in the longer term. The research that was conducted by Dirajral-Fargo et al in [17] found that insulin resistance marked by an increase in HOMA-IR from basic value appeared at 4 weeks after administration of atazanavir/ritonavir (ATV/r) and tenofovir/emtricitabine (TDF/FTC) raltegravir (RAL), or darunavir/ritonavir (DRV/r)

The mean duration of subject using ARV drugs specifically PI- type, range between 6 to 12 months, is 22 people (60\%). Some research that study the duration of using ARV drugs with the long-term side effects of insulin resistance have different durations. Noor et al [10] reported that the administration of LPV / $\mathrm{r}$ (lopinavi / ritonavir) for 5 days could induce insulin resistance, but in this study the effect of LPV / $r$ was not assessed in the longer term. Meanwhile, DirajralFargo et al [17] study discover that insulin resistance that was marked by an increase in HOMAIR from baseline appeared at 4 weeks after administration of tenofovir/emtricitabine (TDF / FTC) plus atazanavir/ritonavir (ATV / r), darunavir/ritonavir (DRV / r), or raltegravir (RAL).

The mean fasting blood glucose of the subjects was 86 (70-283) $\mathrm{mg} / \mathrm{dl}$ and levels of fasting insulin of the subjects was $9,1(4,1-79,4)(\mu \mathrm{U} / \mathrm{ml})$. Previous research have a slight difference results from this study whereas patients who received ARV drugs was 96.4 (88-103) mg/dl with fasting insulin levels of 12.8 (3.2-14.8) $\mu \mathrm{U} / \mathrm{ml}$ [13]. However, both blood glucose levels and fasting insulin levels from either study was still within normal value. According to Perkeni 2015 
in [18] states that the normal value of fasting blood glucose were $<100 \mathrm{mg} / \mathrm{dl}$, while Rajos et al in [19] recommends normal fasting insulin levels when the levels are $<13 \mu \mathrm{U} / \mathrm{ml}$.

The mean ureum levels in subject of this research was $20.88 \pm 9.7 \mathrm{mg} / \mathrm{dl}$. While the mean creatinine levels were $0.81 \pm 0.15 \mathrm{mg} / \mathrm{dl}$. Therefore it can concluded that all of the subjects renal function is still normal, in spite of the use of ARV drugs for 6-12 months. This results correspondence with the previous research that was conducted by Budiman in [20] who reported that HIV patients that received ARV had an average ureum level of $19.95 \pm 9.56 \mathrm{mg} / \mathrm{dl}$ and a mean creatinine level of $0.82 \pm 0.19 \mathrm{mg} / \mathrm{dl}$ [20]. Data that shows of the characteristics of subjects in this study presented in table 1 below.

Table 1 The Subjects Characteristics*

\begin{tabular}{|c|c|c|}
\hline Subjects Characteristic & Mean & n (\%) \\
\hline Age. (year) & $38.85 \pm 9.7$ & \\
\hline $\begin{array}{l}\text { Gender } \\
\text { - Male } \\
\text { - Female }\end{array}$ & & $\begin{array}{l}25(71.4) \\
10(28.6)\end{array}$ \\
\hline Body Mass Index $\left(\mathrm{kg} / \mathrm{m}^{2}\right)$ & $24.35 \pm 3.9$ & \\
\hline Blood Pressure (mm Hg) & & \\
\hline SBP & $110.57 \pm 10.2$ & \\
\hline DBP & $74.57 \pm 7.4$ & \\
\hline $\begin{array}{l}\text { HOMA IR } \\
\text { - With Insulin Resistance } \\
\text { - Without Insulin Resistance }\end{array}$ & $\begin{array}{l}3.64 \pm 4.4 \\
7.44 \pm 5.4 \\
1.40 \pm 0.4\end{array}$ & \\
\hline $\begin{array}{l}\text { Fasting Blood Glucose }(\mathrm{mg} / \mathrm{dl}) \\
\text { Fasting Insulin }(\mu \mathrm{U} / \mathrm{ml}) \\
\text { Ureum }(\mathrm{mg} / \mathrm{dl}) \\
\text { Creatinine }(\mathrm{mg} / \mathrm{dl})\end{array}$ & $\begin{array}{c}96.6 \pm 36.8 \\
14.77 \pm 17.4 \\
20.88 \pm 5.7 \\
0.81 \pm 0,15\end{array}$ & \\
\hline
\end{tabular}

\subsection{Comparison of Renal Function Test According to The Duration of Treatment}

Comparison of the mean ureum and creatinine levels based on the duration of treatment presented that there were no significant differences in the levels of ureum and creatinine in the two groups of treatment, respectively $(p=0.226 ; p=0.168)$. For the complete data on urea and creatinine levels and the comparison of the two based on the length of treatment for this type of PI ARV research is presented in Table 2 below. 
Table 2 Comparison of Renal Function Based on Duration of Treatment

\begin{tabular}{lccc}
\hline \multicolumn{1}{c}{ Variable } & $\mathbf{6 - 1 2}$ months & $>$ 12 months & $\boldsymbol{p}$ \\
& & & \\
\hline Ureum $(\mathrm{mg} / \mathrm{dl})$ & $19.9 \pm 5.71$ & $22.35 \pm 5.81$ & 0.226 \\
Creatinine $(\mathrm{mg} / \mathrm{dl})$ & $0.75 \pm 0.15$ & $0.86 \pm 0.13$ & 0,168 \\
\hline
\end{tabular}

Dependent T-Test for abnormal distribution

Therefore, it can be concluded that the levels of ureum and creatinine in the two groups of treatment did not differ significantly and both were still within normal limits. These results resemble with the research that was conducted by Yeboah et al in [21]. Whom also reported that after 6 months of ARVs there were a slight decrease in GFR but the levels of ureum and creatinine were still within normal limits. Yeboah et al in [21] also added that there was no difference in glomerular filtration rate (GFR) based on the duration of ARV administration. Duration of ARVs in this case is divided into $<2$ years and $\geq 2$ years. The description of mean levels of ureum and creatinine is presented in the graph below

\subsection{The Correlation Of Duration Of Treatment With Insulin Resistance}

Tabel 3 The correlation of duration of with insulin resistance

\begin{tabular}{|c|c|c|c|c|c|}
\hline \multirow{2}{*}{ Variable } & \multicolumn{2}{|c|}{$\begin{array}{c}\text { Insulin Resistance } \\
\mathrm{n}(\%)\end{array}$} & \multirow{2}{*}{$P$} & \multirow{2}{*}{ OR } & \multirow{2}{*}{ IK 95\% } \\
\hline & & $\mathrm{N}$ & & & \\
\hline $\begin{array}{l}\text { Duration Of Treatment } \\
\qquad \quad 6-12 \text { month } \\
\bullet \quad>12 \text { months }\end{array}$ & $\begin{array}{l}4(42.9) \\
9(87.5)\end{array}$ & $\begin{array}{l}17(57.1) \\
5(12.5)\end{array}$ & $0.018 *$ & 7.65 & $1.63-35.79$ \\
\hline
\end{tabular}

Based on table 3. it shows that the subjects of the study with $>12$ months ARV treatment that had insulin resistance was $87.5 \%$ while the subjects with 6-12 months ARV treatment that had insulin resistance was $49,2 \%$, it can be concluded that the subjects with $>12$ months treatment have higher percentage compare to the subjects with 6-12 months of treatment. Based on chi square analysis results, that were obtained there was a significant relation between the duration of ARV treatment with insulin resistance $9 \mathrm{p}=0.018$; OR 7.65). It also can be concluded that patient with $>12$ months of ARV treatment has a risk 7.65 times greater than patient with 6-12 months of ARV treatment. According to Permenkes in [11], reported that the toxicity of ARV after 6-18 
months administration can cause the metabolic abnormality that generally happen by PI (protease inhibitor), include hyperlipidemia, accumulation of lipid insulin resistance, diabetes and osteopenia [22]. The insulin resistance percentage according to length of treatment in this research is presented in the graph below.

Along with Fiesha and Belete in [23] research, also reported there was a relation between duration of ARV treatment with incidence of diabetes mellitus ( $p=0.021$; $\mathrm{OR}=2.67$ ). Based on Gullein et al in [2], stated that there was also a relation between the use of ARV and insulin resistance. In that study, insulin resistance prevalence was $34 \%$, 2 times higher than population patient without HIV. Study by Gullein et al in [2] did not use control, therefore use a cutoff value HOMA-IR was 2,1 based on previous reasearch in Hospital Nacional Cavetano Heredia with similar characteristics ethnics and geographics Moreover, other factors that aggravated the relation of insulin resistance and usage of ARV was age and BMI. The variety of mechanism in impaired glucose metabolism in adult HIV patients was the cause of direct effect from HIV infection, side effect of ARV, inflammation and other risk factor of decreased glucose metabolism. Side effects of anti-HIV protease inhibitor and NNRTI related with the increasing risk of diabetes and insulin resistance. [17]. Some researches also stated that there is a correlation between the use of PI with the incidence of lipodystrophy, dyslipidemia and insulin resistance. In physiological concentration there is also a distinction of the level of metabolic effects of PI [24].

Some review said the drugs that contain PI, which cause insulin resistance in HIV patients can be explained by three assumption: inhibiton of GLUT-1 and GLUT-4 in membran plasma, inhibition from differentiation pre adipocyte/adipocyte, and induced apoptosis in adipose. Study by Hruz and Murata et al in [6] suggest that main mechanism that responsible in induced insulin resitance was inhibition of glucose transporter. PI selectively and potentially decrease activity of GLUT-4, without altering the signalling mechanism of insulin or translocation of GLUT-4. The GLUT-4 itself work to limited the step of glucose elimination, inhibition effect of PI on GLUT-4 cause insulin resistance in patients with HIV. Few patients can suffer diabetes as a result from beta pancreatic cell failure to compensate this resistance.[6]-[25]-[26]

In normal muscle and fat tissue, GLUT-4 was recycled in between the cell plasma and intracelluler storage. If there is insulin, this balance will change that can cause translocation receptor for intracelluler to plasma membrane. The effect is increase maximum of glucose transport rate into cell. Translocation GLUT-4 intracelluler induce 
by insulin, actually starts from binding insulin to receptors in extracelluler part. This binding triggers several reactions of phosphorilation which is very important to action of insulin. Autophosporilation in tyrosin amino acid that was trigger by insulin and happen in cytoplasm domain from receptors will strengthen action of tyrosin kinase enzyme, which the phosphorilizes several intracelluler protein including Insulin Receptor Substrate-1 (IRS-1). Phosphorillation from IRS-1 results in secondary signals that connect the insulin receptor on glucose transport transmembran. Furthermore, the activation of phosphatidylinositol 3-kinases is necessary to stimulate glucose transport using insulin and needed to induced translocation from GLUT-4 to plasma membrane. [27]

\section{Conclusion}

Based on the analysis of the data obtained in this study it can be establish that there is a significant correlation between the length of ARV treatment with insulin resistance. The prolonged use of Protease Inhibitors will further increase insulin resistance.

\section{REFERENCES}

[1] World Health Organization. WHO case definitions of HIV for surveillance and revised clinical staging and immunological classification of HIV-related disease in adults and children. World Health Organization. 2007 [Online]. Available: https://apps.who.int/iris/handle/10665/43699. [Accessed: August 06 2019]

[2] Guillen, M. A. Mejia, F.A., Villena, J., Turin, C.G., Carcamo, C.P., Ticse, R. Insulin resistance by homeostasis model assessment in HIV-infected patients on highly active antiretroviral therapy: Cross-sectional study, Diabetology and Metabolic Syndrome. vol. 7, no. 49, pp.1-6. 2015

[3] Ohnishi, H., Saitoh, S., Ura, N., Takagi, S., Obara, F., Akasaka, H., et al. Relationship between insulin resistance and accumulation of coronary risk factors. Diabetes, Obesity, and Metabolism. vol. 4, no. 6, pp.388-393. November. 2002

[4] Bermudez, V., Salazar, J., Martínez, M.S., Chávez-Castillo, M., Olivar, L.C., Calvo, M.J., et al. 2016. Prevalence and Associated Factors of Insulin Resistance in Adults from Maracaibo City, Venezuela. Advances in preventive medicine. pp. 1-3 Augustus 2016. 
[5] Pushpakom, S.P. Adaikalakoteswari, A., Owen, A., Back, D.J., Tripathi, G., Kumar, S. et al. Telmisartan reverses antiretroviral-induced adipocyte toxicity and insulin resistance in vitro. Diabetes and Vascular Disease Research, vol.15, no. 3, pp. 233-242. Feb 2018.

[6] Murata H, Hruz PW, Mueckler M. Indinavir inhibits the glucose transporter isoform Glut-4 at physiologic concentrations. AIDS. vol.16, pp. 859-863, May 2002.

[7] Koster, J. C., Remedi, M.S., Qiu, H., Nichols, C.G., Hruz, P.W. HIV protease inhibitors acutely impair glucose-stimulated insulin release. Diabetes, vol.52, no.7, pp. 1695-1700. 2003.

[8] Overton, E.T., Tebas, P., Coate, B., Ryan, R., Perniciaro, A., Dayaram, Y.K. et al. Effects of once-daily darunavir/ritonavir versus atazanavir/ritonavir on insulin sensitivity in HIV-infected persons over 48 weeks: results of an exploratory substudy of Metabolic, a phase 4, randomized trial. HIV Clinical Trial. Vol. 7, no. 2, pp. 72-77, March 2016.

[9] Carr, A., Samaras, K., Thorisdottir, A., Kaufmann, G.R., Chisholm, D.J., Cooper, D.A. Diagnosis, Prediction, and Natural Course of HIV-1 Protease-inhibitorassociated Lipodystrophy, Hyperlipidaemia and Diabetes Mellitus: A Cohort Study. Lancet. Vol. 353, no. 9170, pp. 2093-2100. June 1999.

[10] Noor, M.A., Parkerd, R.A., O’Marab, E., Graselab, D.M., Currieb, A., Hoddera, S.L. et al. The effects of HIV protease inhibitors atazanavir and lopinavir/ritonavir on insulin sensitivity in HIV-seronegative healthy adults. AIDS. vol.18, no 16, pp. 2137-2144. November 2004.

[11] Ministry of Health. Regulation of the Minister of Health of The Republic of Indonesia Number 87 of 2014 on on Guidelines of the Antiretroviral Treatment. Ministry of Health of the Republic of Indonesia, Jakarta. [Online]. Available: https://drive.google.com/file/d/1jzQEop1SsHFehMx-4jcp8JRC6J3kjYCp/view.

[Accessed: August 08, 2019]

[12] Qu, H., Li, Q., Rentfro, A.R., Fisher-Hoch, S.P., McCormick, J.B. The Definition of Insulin Resistance Using HOMA-IR for Americans of Mexican Descent Using Machine Learning. Ploseone. Vol.6, no.6, 2011.

[13] Araujo, S., Banon, S., Machuca, I., Moreno, A., Perez-Elıas, M. J and Casado, J.L. Prevalence of insulin resistance and risk of diabetes mellitus in $\mathrm{HIV}$-infected patients receiving current antiretroviral drugs. European Journal of Endocrinology. Vol. 171, no. 5, pp. 545-554. November 2014. 
[14] Mulyati, M., Subagio,H.,W., dan Udji, M.,A. Hubungan Lama Pemberian Terapi Anti Retroviral Dengan Komposisi Tubuh Pada Pasien HIV. Journal of Nutrition and Health. Vol.5, no.2, pp. 129-137. June 2017

[15] Saktina, P.U. Karakteristik Penderita AIDS dan Infeksi Oportunistik di Rumah Sakit Umum Pusat Sanglah Denpasar Periode Juli 2013 sampai Juni 2014, E-Jurnal Medika Udayana. Vol. 6, no.3, pp. 1-6. 2017

[16] Salazar, J. Bermúdez, V., Calvo, M., Olivar L.C., Luzardo E., Navarro, C. et al. Optimal cutoff for the evaluation of insulin resistance through triglyceride-glucose index: A cross-sectional study in a Venezuelan population. F1000Research. Vol.6, no. 1337 , pp. $1-15.2018$

[17] Dirajlal-Fargo, S., Moser, C., Brown, T.T, Kelesidis, T., Dube, M.P., Stein, J.H. et al. Changes in Insulin Resistance After Initiation of Raltegravir or Protease Inhibitors With Tenofovir-Emtricitabine: AIDS Clinical Trials Group A5260s. Open Forum Infectious Disease. Vol.3, no.3, pp. 174. Augustus 2016.

[18] Perkeni. Consensus On The Management And Prevention Of Type 2 Diabetes Mellitus In Indonesia. PB. Perkeni. 2015. [Online]. Available: https://pbperkeni.or.id/wpcontent/uploads/2019/01/4.-Konsensus-Pengelolaan-dan-Pencegahan-Diabetes-melitustipe-2-di-Indonesia-PERKENI-2015.pdf [Accessed : August 08, 2019]

[19] Rojas, J. Biologic Behavior and optimal cut-off point estimation for Serum Fasting Insulin: A report from the Maracibo City Metabolic Synrome Prevalence Study. Revista Latinoamericana de Hipertensión. Vol.7, no.4, pp. 80-82. June 2012.

[20] Budiman, A. The Effect of Tenofovir on the Occurrence of Microalbuminuria in People with HIV / AIDS Receiving Antiretroviral Therapy [Dissertation]. Universitas Sumatera Utara : Medan. 2017. [Online]. Available : The University Institusional Repository Of Universitas Sumatera Utara. [Accessed : August 08, 2019]

[21] Yeboah, D.O. Awuku, Y.A. Alofa, W. Charwudzi, A. Aniakwa-Bonsu, E. Evans Obboh., et al. Renal dysfunction among adult HIV/AIDS patients on antiretroviral therapy at a tertiary facility in Ghana. BMC Nephrology. Vol. 19, no.1. 333. November 2018.

[22] Ministry of Health. Regulations of the Minister of Health of the Republic of Indonesia Number 21 of 2013 on HIV and AIDS prevention. Ministry of the Republic of Indonesia, Jakarta. [Online]. Available: http://ditjenpp.kemenkumham.go.id/arsip/bn/2013/bn654-2013.pdf. Accessed: [Accessed : August 08, 2019] 
[23] Fiseha, T., and Belete., A.,G. Diabetes mellitus and its associated factors among human immunodeficiency virus infected patients on antiretroviral therapy in Northeast Ethiopia. BMC Res Notes, Vol. 12, no. 1, pp. 372, July 2019.

[24] Florescu, D., Kotler, D.P. Insulin Resistance, Glucose Intolerance and Diabetes Mellitus in HIV-infected Patients. Antiviral Therapy. Vol. 12, no. 2, pp. 149-162, January 2007.

[25] Pedro, M. N., Rocha, G.Z., Guadagnini, D. Santos, A., Magro, D.O., Assalin, H.B., et al. Insulin resistance in HIV-patients: causes and consequences. Frontiers in endocrinology. Vol. 9, no. 514, September 2018.

[26] Kramer, A. S., Lazzarotto, A.R., Sprinz, E., Manfroi, W.C. Metabolic abnormalities, antiretroviral therapy and cardiovascular disease in elderly patients with HIV. Arquivos brasileiros de cardiologia. Vol. 93, no. 5, pp. 561-568, November 2009.

[27] Tjandrawinata, R.R. Patogenesis Diabetes Tipe 2: Resistensi Insulin dan Defisiensi Insulin [Online]. Available from : https://www.researchgate.net/publication/292615802. [Accessed : August 08, 2019] 